\title{
Analisis Faktor Penyebab Terjadinya Kredit Macet
}

\author{
Andi Nursyahriana ${ }^{1}$, Michael Hadjat ${ }^{2}$, Irsan Tricahyadinata ${ }^{3}$ \\ Fakultas Ekonomi dan Bisnis Universitas Mulawarman, Indonesia \\ Email: syhriana@gmail.com
}

\begin{abstract}
Abstrak
Penelitian ini bertujuan untuk mengetahui pengaruh debitur yaitu karakter debitur, kapasitas, kondisi ekonomi, dan agunan debitur terhadap kredit bermasalah pada PT Bank Tabungan Negara Cabang Bontang. Penelitian ini dilakukan di Kota Bontang. Metode yang digunakan dalam penelitian ini adalah survei lapangan dengan menggunakan kuesioner terhadap 32 responden pada status debitur bermasalah. Pengambilan sampel menggunakan metode cencus. Data dianalisis dengan menggunakan regresi linier berganda dalam analisis statistik dengan bantuan program SPSS ver. 20. Hasil penelitian yang dilakukan menunjukkan bahwa variabel karakter (X1) berpengaruh signifikan dan negatif terhadap non performing loan (Y), kapasitas (X2) berpengaruh tidak signifikan dan negatif terhadap non performing loan (Y), variabel kondisi ekonomi (X3) memiliki pengaruh yang tidak signifikan dan negatif terhadap kredit bermasalah (non performing loans / Y), dan variabel agunan (X4) memiliki pengaruh yang tidak signifikan dan negatif terhadap kredit bermasalah (non performing loans / Y). Kata Kunci: non performing loan
\end{abstract}

\section{Factor Analysis of Causes of Bad Debt}

\begin{abstract}
This research aims to know the influence of debtors i.e. character of debtor, capacity, condition of economy, and collateral of debtor against non performing loans at PT Bank Tabungan Negara Cabang Bontang. This research was conducted in Bontang City. The methods used in this research was field survey by using questionnaire to 32 respondents in troubled debtor status. Sampling using cencus method. Data were analyzed by using multiple linear regression in statistical analysis with the help of the program SPSS ver. 20. Results of research conducted indicates that the variable character (X1) have significant and negative effect on non performing loans (Y), capacity (X2) have non significant and negative effect on non performing loans (Y), the variable condition of economy (X3) have non significant and negative effect on non performing loans (Y), and variable collateral (X4) have non significant and negative effect on non performing loans (Y).
\end{abstract}

Keywords: non performing loan 


\section{PENDAHULUAN}

Perbankan berperan dalam pembangunan ekonomi dengan mengalirkan dana dalam bentuk perkreditan bagi masyarakat perorangan atau badan usaha untuk memenuhi kebutuhan konsumsinya atau untuk meningkatkan produksinya. Kebutuhan yang menyangkut kebutuhan produktif misalnya untuk meningkatkan dan memperluas kegiatan usahanya. Kepentingan yang bersifat konsumtif misalnya untuk membeli rumah sehingga masyarakat dapat memanfaatkan pendanaan dari Bank yang dikenal Kredit Kepemilikan Rumah disingkat KPR. Salah satu Bank Milik Negara yang secara luas telah menyediakan pendanaan bagi masyarakat untuk membeli rumah dengan berbagai type, dan harga adalah Bank Tabungan Negara (BTN).

Dana yang digunakan Bank untuk membiayai kredit tersebut bukan semata-mata berasal dari modal Bank tetapi sebagian besar berasal dari dana-dana masyarakat. Menurut Hermanto, modal Bank sangat terbatas sehingga untuk mengembangkan usaha, Bank harus berusaha keras menarik dana dari masyarakat yang yang kemudian disalurkan kembali kepada masyarakat. Inilah yang disebut Bank menjalankan fungsi intermediasi. Dana-dana masyarakat yang bisa ditarik dari masyarakat misalnya tabungan, giro, deposito, sertifikat deposito, obligasi dan surat-surat hutang lainnya. Peranan perkreditan cukup dominan dalam suatu negara yang sedang berkembang dalam rangka mengembangkan potensi ekonomi (Hermanto, 2006: 2).

Berdasarkan ketentuannya Bank Indonesia (BI) menggolongkan kualitas kredit yaitu (1) Lancar (pas) artinya kredit yang disalurkan tidak menimbulkan masalah, (2) dalam perhatian khusus (special mention) artinya kredit yang diberikan sudah mulai bermasalah, sehingga perlu memperoleh perhatian, (3) kurang lancar (substandard) apabila kredit yang diberikan pembayarannya sudah mulai tersendat-sendat, namun nasabah masih mampu membayar, (4) diragukan (doubtful) yaitu kemampuan nasabah untuk membayar makin tidak dapat dipastikan, dan (5) macet (loss) apabila nasabah sudah tidak mampu lagi untuk membayar pinjamannya, sehingga perlu diselamatkan (Febrianti, 2015:2)

Pemberian kredit yang berjalan lancar akan mengembangkan dan meningkatkan kegiatan ekonomi suatu negara. Karena pinjaman yang diberikan Bank dalam bentuk kredit tersebut berasal dari dana masyarakat maka memiliki resiko (risk asset) yang tinggi yaitu tidak kembalinya kredit itu tepat pada waktunya yang dinamakan Non Performing Loan (NPL). Dimana tingkat kesehatan bank salah satunya diukur dari tingkat rasio Kredit Bermasalah (Non Performing Loan) atau biasa dikenal sebagai "Rasio NPL” (Hariyani, 2008: 66). Yang akibatnya dapat mengganggu likuiditas Bank.

Kredit macet adalah bagian dari kredit bermasalah. Kredit macet terjadi jika pihak bank mengalami kesulitan untuk meminta angsuran dari pihak debitur karena suatu hal. Kredit macet adalah piutang yang tak tertagih atau kredit yang mempunyai kriteria kurang lancar, diragukan karena mengalami kesulitan pelunasan akibat adanya faktor-faktor tertentu (Hermanto, 2006: 17)

Menurut Hariyani (2008), Kredit macet dapat disebabkan oleh faktor internal maupun eksternal. Faktor internal penyebab kredit macet yaitu: kebijakan perkreditan yang ekspansif, menyimpang dalam pelaksanaan prosedur perkreditan, itikad kurang baik dari pemilik, pengurus atau pegawai bank, lemahnya sistem informasi kredit macet. Sedangkan faktor eksternal penyebab kredit macet adalah: kegagalan usaha debitor, pemanfaatan iklim persaingan perbankan yang tidak sehat oleh debitur, serta menurunnya kegiatan ekonomi dan tingginya suku bunga kredit.

Pengurangan risiko kredit macet dapat diupayakan dengan meneliti faktor-faktor penyebab terjadinya kredit macet. Karena pada dasarnya pihak perbankan sebelum memberikan pelayanan kredit, terlebih dahulu harus menganalisa apakah calon debitur tersebut dapat dipercaya atau diandalkan. Kita mengenal Prinsip 5C sebagai penilaian atas permohonan kredit yaitu: Character (Watak/Kepribadian), Capacity (Kemampuan), Capital (Modal), Condition of economy (Kondisi ekonomi), dan Collateral (Jaminan). (Hadiwidjaja, 2007:34). Dalam penelitian ini, capital tidak dimasukkan dalam variabel penelitian karena debitur yang berstatus kredit macet merupakan debitur perorangan bukan Badan, UMKM ataupun UKM.

Copyright ๑ 2017, FORUM EKONOMI ISSN Print: 1411-1713 ISSN Online: 2528-150X 
Berdasarkan permasalahan dan pembahasan pendahuluan diatas maka penulis melakukan penelitian dengan judul "Analisis Faktor Penyebab Terjadinya Kredit Macet di PT.Bank Tabungan Negara (Persero) Tbk. Cabang Bontang”.

\section{KAJIAN PUSTAKA}

Prinsip pemberian kredit oleh Bank dilakukan untuk mendapatkan nasabah yang benar-benar menguntungkan. Biasanya dikenal dengan analisis 5C. Prinsip pemberian kredit dengan analisis 5C adalah sebagai berikut: (Hadiwidjaja, 2007:34)

1. Character (watak/kepribadian), calon debitur yang mempunyai reputasi baik sajalah yang dapat diteruskan pertimbangan permohonan kreditnya.

2. Capacity (kemampuan), kemampuan calon debitur akan memberikan kejelasan kepada analis, sampai sebatas mana jumlah besar atau kecilnya pendapatan calon debitur. Diharapkan ia akan mampu melakukan pembayaran kembali atas kreditnya

3. Capital (modal), diperlukan untuk mengukur sampai sebesar berapakah tingkat ratio Likuiditas dan Solvabilitasnya (berlaku untuk badan usaha).

4. Condition of economy (kondisi ekonomi), penilaian prospek bidang usaha yang dibiayai hendaknya benar-benar memiliki prospek yang baik sehingga kemungkinan kredit tersebut bermasalah relatif kecil.

5. Collateral (jaminan/angunan), adalah jaminan berupa harta benda milik debitur atau pihak lain yang menjaminnya diikat sebagai anggunan/tanggugan. Yang berfungsi sebagai penentu dalam pemberian kredit dan pengaman atas kredit yang diberikan.

Sedangkan Kredit macet dapat diartikan sebagai pinjaman yang mengalami kesulitan pelunasan akibat adanya faktor kesengajaan dan atau karena faktor eksternal di luar kemampuan kendali debitur (Dahlan, 2001: 174). Dan menurut (Arthesa, 2006) Kredit macet adalah kredit sejak jatuh tempo tidak dapat dilunasi oleh debitur sebagaimana mestinya sesuai dengan perjanjian. Kredit macet merupakan rasio keuangan yang berkaitan dengan risiko kredit.

Dapat disimpulkan bahwa, kredit macet merupakan pinjaman yang mengalami kesulitan oleh debitur untuk memenuhi kewajiban yang telah disepakati bersama antara pihak kreditur dan debitur dikarenakan karena faktor kesengajaan maupun diluar kendali. Kredit bermasalah akan berakibat pada kerugian bank, yaitu kerugian karena tidak diterimanya kembali dana yang telah disalurkan, maupun pendapatan bunga yang tidak dapat diterima. Artinya, bank kehilangan kesempatan mendapat bunga, yang berakibat pada penurunan pendapatan secara total.

\section{Hipotesis Penelitian}

Menurut Duwi Priyatno (2010), uji ini digunakan untuk mengetahui apakah variabel independen (X1, X2, .....X7) secara bersama-sama berpengaruh signifikan terhadap variabel dependen (Y). Adapun Hipotesisnya adalah sebagai berikut:

H1 : Character debitur berpengaruh terhadap kredit macet

$\mathrm{H} 2$ : Capacity berpengaruh terhadap kredit macet

$\mathrm{H} 3$ : Condition of Economy berpengaruh terhadap kredit macet

H4 : Collateralberpengaruh terhadap kredit macet

\section{METODE PENELITIAN}

\section{Definisi Operasional dan Pengukuran Variabel}

Variabel yang akan digunakan dalam penelitian ini adalah sebagai berikut:

1. Independent Variable atau variabel bebas (X), yaitu merupakan variabel yang menjadi sebab timbulnya atau berubahnya variabel dependen. Variabel bebas dalam penelitian ini adalah: 
a. Character (watak/kepribadian), calon debitur yang mempunyai reputasi baik sajalah yang dapat diteruskan pertimbangan permohonan kreditnya. (Kasmir, 2010).

Indikator :

1) Itikad nasabah

2) Tanggungjawab

3) Kejujuran/sifat keterbukaan

b. Capacity (kemampuan), kemampuan calon debitur akan memberikan kejelasan kepada analis, sampai sebatas mana jumlah besar atau kecilnya pendapatan calon debitur. Diharapkan ia akan mampu melakukan pembayaran kembali atas kreditnya. (Supriyono, 2011).

Indikator :

1) Pengelolaan keuangan

2) Perincian

3) Penganggaran

4) Prioritas

5) Pengambilan kebijakan

c. Condition of economy (kondisi ekonomi), penilaian prospek bidang usaha yang dibiayai hendaknya benar-benar memiliki prospek yang baik sehingga kemungkinan kredit tersebut bermasalah relatif kecil. (Kasmir, 2010).

Indikator:

1) Perkembangan kondisi keuangan

2) Kemampuan menyisihkan penghasilan

3) Pendapatan yang cukup

4) Adanya tanggungan lain

5) Penghasilan relatif

6) Lingkungan

d. Collateral (jaminan/angunan), adalah jaminan berupa harta benda milik debitur atau pihak lain yang menjaminnya diikat sebagai anggunan/tanggugan. Yang berfungsi sebagai penentu dalam pemberian kredit dan pengaman atas kredit yang diberikan. (Suyatno, dkk, 1997)

Indikator:

1) Keberadaan jaminan

2) Sifat jaminan

3) Kondisi jaminan

4) Nilai jaminan

5) Kepemilikan jaminan

6) Keaslian dokumen jaminan

7) Kelengkapan dokumen jaminan

2. Dependent Variable atau variabel terikat (Y), yaitu variabel yang tergantung pada variabel lain. Dalam penelitian ini adalah faktor penyebab terjadinya kredit macet. Kredit macet merupakan kredit yang telah disalurkan oleh bank, dan nasabah tidak dapat melakukan pembayaran atau melakukan angsuran sesuai dengan perjanjian yang telah ditandatangani oleh bank dan nasabah. Indikator adalah:

1) Terdapat tunggakan pembayaran angsuran pokok dan/atau bunga yang telah melampaui 90 hari (3 bulan)

2) Surat peringatan

3) Pelanggaran kontrak

4) Perpanjangan kredit

5) Kerugian operasional ditutup dengan pinjaman baru

6) Pelunasan dengan angunan

7) Tindak lanjut kredit macet 


\section{Jangkauan Penelitian}

Adapun jangkauan dalam penelitian ini adalah sebatas nasabah kedit Bank Tabungan Negara Cabang Bontang yang berstatus debitur bermasalah.

\section{Populasi dan Sampel}

Populasi adalah wilayah generalisasi yang terdiri atas: objek/subjek yang mempunyai kualitas dan karakteristik tertentu yang ditetapkan oleh peneliti untuk dipelajari dan kemudian ditarik kesimpulannya. Sedangkan sampel adalah

bagian atau jumlah dan karakteritik yang dimiliki oleh populasi tersebut. Bila populasi besar, dan peneliti tidak mungkin mempelajari semua yang ada pada populasi, misal karena keterbatasan dana, tenaga dan waktu, maka peneliti akan mengambil sampel dari populasi itu. Apa yang dipelajari dari sampel itu, kesimpulannya akan diberlakukan untuk populasi. Untuk itu sampel yang diambil dari populasi harus betul-betul representative (Sugiyono,2011).

Populasi dalam penelitian ini yaitu seluruh nasabah Kredit Pembelian Rumah (KPR) dan Kredit Angunan Rumah (KAR) Bank Tabungan Negara Cabang Bontang. Dan sampel penelitiannya adalah seluruh nasabah kredit KPRdan KARyang berstatus debitur bermasalah. Periode tahun 2016 yang berjumlah 32. Pengambilan sampel dilakukan dengan metode sensus.

\section{HASIL DAN PEMBAHASAN}

Pada bagian ini, menguraikan hasil penelitian dan pembuktian hipotesis, kemudian dilanjutkan dengan pembahasan hasil temuan tersebut. Teknik analisis yang dipergunakan adalah SPSS ver. 20 untuk menguji hubungan antar variabel yang sudah dihipotesiskan.

\section{Deskripsi Hasil Tanggapan Responden}

Berdasarkan hasil kuesioner yang disebarkan kepada debitur bermasalah PT. Bank Tabungan Negara (Tbk.) Cabang Bontang, maka diperoleh sejumlah data sebagai berikut.

\section{Variabel Character (X1)}

Character adalah sifat atau watak yang akan diberikan kredit harus dapat dipercaya yang tercermin dari latar belakang nasabah baik yang bersifat pekerjaan maupun yang bersifat pribadi seperti: cara hidup atau gaya hidup yang dianutnya, keadaan keluarga, hobi dan sosial standingnya. Character merupakan ukuran untuk menilai kemauan nasabah untuk membayar kreditnya. Indikator-indikator character adalah sebagai berikut:

1) Itikad nasabah

2) Tanggungjawab

3) Kejujuran / sifat keterbukaan 
Tabel 1. Rekapitulasi persentase tanggapan responden terhadap variabel character yang mempengaruhi kredit macet di PT. Bank Tabungan Negara Cabang Bontang.

\begin{tabular}{cccccccc}
\hline \multirow{2}{*}{ Indikator } & \multirow{2}{*}{ Simbol } & \multicolumn{5}{c}{ Skala Jawaban } & \multirow{2}{*}{ Mean } \\
\cline { 3 - 6 } & & 1 & 2 & 3 & 4 & 5 & \\
\hline Itikad Nasabah & $\mathrm{X} 1.1$ & & 1 & 8 & 20 & 3 & 3,8 \\
Tanggungjawab & $\mathrm{X} 1.2$ & & 2 & 13 & 14 & 3 & 3,6 \\
Kejujuran / sifat keterbukaan & $\mathrm{X} 1.3$ & & 1 & 11 & 14 & 6 & 3,8 \\
Rerata & & & $\mathbf{1}$ & $\mathbf{1 1}$ & $\mathbf{1 6}$ & $\mathbf{4}$ & $\mathbf{3 , 7}$ \\
\hline$\%$ & & & $3 \%$ & $34 \%$ & $50 \%$ & $13 \%$ & \\
\hline
\end{tabular}

Sumber: Data Primer yang diolah (2017)

Berdasarkan Tabel 1 menunjukkan bahwa, 1 responden atau 3\% pada variabel character debitur Bank BTN Bontang dengan menyatakan jawaban tidak setuju, 11 reponden atau $34 \%$ dengan jawaban cukup setuju, 16 responden atau 50\% dengan jawaban setuju, dan 4 responden atau $13 \%$ dengan jawaban sangat setuju.

Berdasarkan data nilai rata-rata variabel character yang mempengaruhi kredit macet di PT. Bank Tabungan Negara Cabang Bontang menunjukkan nilai sebesar 3,7. Dengan demikian dapat disimpulkan bahwa character debitur yang tergolong baik bukan penyebab adanya kredit macet.

\section{Variabel Capacity (X2)}

Capacity merupakan tolak ukur untuk melihat kemampuan calon nasabah dalam membayar kredit yang dihubungkan dengan kemampuannya mengelola keuangan serta kemampuannya mencari peluang. Sehinggga akan terlihat kemampuannya dalam mengembalikan kredit yang disalurkan. Indikator-indikator capacity adalah sebagai berikut:

1) Pengelolaan keuangan

2) Perincian

3) Penganggaran

4) Prioritas

5) Pengambilan kebijakan

Tabel 2. Rekapitulasi persentase tanggapan responden terhadap variabel capacity yang mempengaruhi kredit macet di PT. Bank Tabungan Negara Cabang Bontang.

\begin{tabular}{cccccccc}
\hline \multirow{2}{*}{ Indikator } & \multirow{2}{*}{ Simbol } & \multicolumn{7}{c}{ Skala Jawaban } & \multirow{2}{*}{ Mean } \\
\cline { 3 - 7 } & & 1 & 2 & 3 & 4 & 5 & \\
\hline Pengelolaan keuangan & $\mathrm{X} 2.1$ & & & 8 & 18 & 6 & 3,9 \\
Perincian keuangan & $\mathrm{X} 2.2$ & & 2 & 11 & 14 & 5 & 3,7 \\
Penganggaran & $\mathrm{X} 2.3$ & & 1 & 6 & 11 & 14 & 4,2 \\
Prioritas & $\mathrm{X} 2.4$ & & 2 & 2 & 14 & 14 & 4,3 \\
Pengambilan Kebijakan & $\mathrm{X} 2.5$ & 1 & & 6 & 15 & 10 & 4,0 \\
Rerata & & $\mathbf{0}$ & $\mathbf{1}$ & $\mathbf{7}$ & $\mathbf{1 4}$ & $\mathbf{1 0}$ & $\mathbf{4 , 0}$ \\
\hline$\%$ & & & $3 \%$ & $22 \%$ & $44 \%$ & $31 \%$ & \\
\hline
\end{tabular}

Sumber: Data Primer yang diolah (2017)

Berdasarkan Tabel 2 menunjukkan bahwa, 1 responden atau 3\% pada variabel capacity debitur Bank BTN Bontang dengan menyatakan jawaban tidak setuju, 7 reponden atau $22 \%$ dengan jawaban cukup setuju, 14 responden atau $44 \%$ dengan jawaban setuju, dan 10 responden atau $31 \%$ dengan jawaban sangat setuju. 
Berdasarkan data nilai rata-rata variabel capacity yang mempengaruhi kredit macet di PT. Bank Tabungan Negara Cabang Bontang menunjukkan nilai sebesar 4,0. Dengan demikian dapat disimpulkan bahwa capacity debitur yang baik bukan penyebab adanya kredit macet.

\section{Variabel Condition of Economy (X3)}

Condition of economy, kondisi ekonomi pada masa sekarang dan yang akan datang harus dinilai sesuai dengan bidang pekerjaan masing-masing. Kondisi ekonomi (pendapatan relatif cukup) hendaknya memiliki prospek yang baik, sehingga kemungkinan kredit tersebut bermasalah relatif kecil. Indikatorindikator condition of economy adalah sebagai berikut:

1) Perkembangan kondisi keuangan

2) Kemampuan menyisihkan penghasilan

3) Pendapatan yang cukup

4) Adanya tanggungan lain

5) Penghasilan relatif

6) Lingkungan

Tabel 3. Rekapitulasi persentase tanggapan responden terhadap variabel condition of economy yang mempengaruhi kredit macet di PT. Bank Tabungan Negara Cabang Bontang.

\begin{tabular}{cccccccc}
\hline \multirow{2}{*}{ Indikator } & \multirow{2}{*}{ Simbol } & \multicolumn{7}{c}{ Skala Jawaban } & \multirow{2}{*}{ Mean } \\
\cline { 3 - 7 } & & 1 & 2 & 3 & 4 & 5 & \\
\hline Perkembangan kondisi keuangan & $X 3.1$ & 1 & 5 & 1 & 12 & 13 & 4,0 \\
Kemampuan menyisihkan penghasilan & $X 3.2$ & & 8 & 4 & 11 & 9 & 3,7 \\
Pendapatan yang cukup & X3.3 & & 2 & 3 & 17 & 10 & 4,1 \\
Adanya tanggungan lain & X3.4 & & & 5 & 17 & 10 & 4,2 \\
Penghasilan relatif & X3.5 & & 9 & & 14 & 9 & 3,7 \\
Lingkungan & X3.6 & & 3 & 3 & 11 & 15 & 4,2 \\
Rerata & & $\mathbf{0}$ & $\mathbf{4}$ & $\mathbf{3}$ & $\mathbf{1 4}$ & $\mathbf{1 1}$ & $\mathbf{4 , 0}$ \\
\hline$\%$ & & & $13 \%$ & $9 \%$ & $44 \%$ & $34 \%$ & \\
\hline
\end{tabular}

Sumber: Data Primer yang diolah (2017)

Berdasarkan Tabel 4.3 menunjukkan bahwa, 4 responden atau $13 \%$ pada variabel condition of economy debitur Bank BTN Bontang dengan menyatakan jawaban tidak setuju, 3 reponden atau 9\% dengan jawaban cukup setuju, 14 responden atau 44\% dengan jawaban setuju, dan 11 responden atau 34\% dengan jawaban sangat setuju. Berdasarkan data nilai rata-rata variabel condition of economy yang mempengaruhi kredit macet di PT. Bank Tabungan Negara Cabang Bontang menunjukkan nilai sebesar 4,0. Dengan demikian dapat disimpulkan bahwa condition of economy debitur yang baik bukan penyebab adanya kredit macet.

\section{Variabel Collateral $(\mathbf{X} 4)$}

Collateral merupakan jaminan yang diberikan calon nasabah baik yang bersifat fisik maupun non fisik. Jaminan hendaknya melebihi jumlah kredit yang diberikan. Jaminan juga harus diteliti keabsahannya sehingga jika terjadi suatu masalah, jaminan yang dititipkan akan dapat dipergunakan secepat mungkin. Indikator-indikator condition of economy adalah sebagai berikut:

1) Keberadaan jaminan

2) Sifat jaminan

3) Kondisi jaminan

4) Nilai jaminan

5) Kepemilikan jaminan

6) Keaslian dokumen jaminan

7) Kelengkapan dokumen jaminan 
Tabel 4. Rekapitulasi persentase tanggapan responden terhadap variabel collateral yang mempengaruhi kredit macet di PT. Bank Tabungan Negara Cabang Bontang.

\begin{tabular}{cccccccc}
\hline Indikator & Simbol & \multicolumn{4}{c}{ Skala Jawaban } & \multirow{2}{*}{ Mean } \\
\cline { 3 - 7 } & & 1 & 2 & 3 & 4 & 5 & \\
\hline Keberadaan jaminan & X4.1 & & 5 & 17 & 10 & 4,2 \\
Sifat jaminan & X4.2 & & 4 & 6 & 12 & 10 & 3,9 \\
Kondisi jaminan & X4.3 & & 5 & 17 & 10 & 4,2 \\
Nilai jaminan & X4.4 & 2 & 10 & 14 & 6 & 3,8 \\
Kepemilikan jaminan & X4.5 & 1 & 5 & 17 & 9 & 4,1 \\
Keaslian dokumen jaminan & X4.6 & 4 & 4 & 20 & 4 & 3,8 \\
Kelengkapan dokumen jaminan & X4.7 & 1 & 4 & 16 & 11 & 4,2 \\
Rerata & & & $\mathbf{2}$ & $\mathbf{6}$ & $\mathbf{1 6}$ & $\mathbf{8}$ & $\mathbf{4 , 0}$ \\
\hline \% & & & $6 \%$ & $19 \%$ & $50 \%$ & $25 \%$ &
\end{tabular}

Sumber: Data Primer yang diolah (2017)

Berdasarkan Tabel 4.4 menunjukkan bahwa, 2 responden atau 6\% pada variabel collateral debiturBank BTN Bontang dengan menyatakan jawaban tidak setuju, 6 reponden atau 19\% dengan jawaban cukup setuju, 16 responden atau $50 \%$ dengan jawaban setuju, dan 8 responden atau $25 \%$ dengan jawaban sangat setuju.

Berdasarkan data nilai rata-rata variabel collateral yang mempengaruhi kredit macet di PT. Bank Tabungan Negara Cabang Bontang menunjukkan nilai sebesar 4,0. Dengan demikian dapat disimpulkan bahwa condition of economy debitur Bank BTN Bontang tergolong baik bukan penyebab adanya kredit macet.

\section{Variabel Kredit Macet (Y)}

Kredit macet merupakan kredit yang telah disalurkan oleh bank, dan nasabah tidak dapat melakukan pembayaran atau melakukan angsuran sesuai dengan perjanjian yang telah ditandatangani oleh bank dan nasabah. Indikator-indikator kredit macetadalah sebagai berikut:

1) Tunggakan ansuran

2) Surat peringatan

3) Melanggar kontrak

4) Perpanjangan kredit

5) Pinjaman baru

6) Tindak lanjut kredit

Tabel 5. Rekapitulasi persentase tanggapan responden terhadap kredit macet di PT. Bank Tabungan Negara Cabang Bontang.

\begin{tabular}{|c|c|c|c|c|c|c|c|}
\hline \multirow{2}{*}{ Indikator } & \multirow{2}{*}{ Simbol } & \multicolumn{5}{|c|}{ Skala Jawaban } & \multirow{2}{*}{ Mean } \\
\hline & & 1 & 2 & 3 & 4 & 5 & \\
\hline Tunggakan angsuran & Y.1 & 20 & 10 & 2 & & & 1,4 \\
\hline Surat peringatan & Y.2 & 27 & 2 & 3 & & & 1,3 \\
\hline Melanggar kontrak & Y.3 & 22 & 7 & 3 & & & 1,4 \\
\hline Perpanjangan kredit & Y.4 & 27 & 2 & 3 & & & 1,3 \\
\hline Pinjaman baru & Y.5 & 24 & 5 & 3 & & & 1,3 \\
\hline Pelunasan dengan angunan & Y.6 & 23 & 5 & 2 & 2 & & 1,5 \\
\hline Tindak lanjut kredit & Y.7 & 23 & 6 & & 2 & 1 & 1,5 \\
\hline Rerata & & 24 & 5 & 2 & 1 & $\mathbf{0}$ & 1,4 \\
\hline$\%$ & & $75 \%$ & $16 \%$ & $6 \%$ & $3 \%$ & & \\
\hline
\end{tabular}

Sumber: Data Primer yang diolah (2017)

Berdasarkan Tabel 4.5 menunjukkan bahwa, 24 responden atau 75\% pada variabel Kredit Macet pada Bank BTN Bontang dengan menyatakan jawaban sangat setuju, 5 reponden atau 16\% dengan 
jawaban setuju, 2 responden atau 6\% dengan jawaban cukup setuju, dan 1 responden atau 3\% dengan jawaban tidak setuju.

Hasil jawaban responden menunjukkan bahwa, semua debituryang menjadi responden tergolong dalam debitur bermasalah, jika ditinjau dari pengaruh keempat variabel tersebut, tak satu pun yang menjadi penyebab kredit macet di Bank BTN Bontang, dengan artian kredit macet dipengaruhi oleh faktor lain.

\section{Analisis Data \\ Uji Validitas Data}

Uji validitas digunakan untuk mengukur valid tidaknya kuisioner. Suatu kuisioner dikatakan valid jika item-item pertanyaannya mampu mengungkapkan susuatu yang hendak diukur oleh kuesioner tersebut. Pengujian validitas dilakukan dengan menggunakan SPPS for Windows Versi 20. Uji validitas menggunakan Pearson yang dibandingkan dengan $\mathrm{R}$ tabel, dimana $\mathrm{R}$ tabel untuk $\mathrm{N}$ sebanyak 32 pada tingkat signifikansi 5\% adalah sebesar 0,2869(lihat di tabel R). Hasil dikatakan valid apabila, Nilai $\mathrm{R}_{\text {hitung }}$ $>\mathrm{R}_{\text {tabel. }}$. Berikut adalah hasil uji validitas dalam penelitian ini:

Tabel 6. Uji Validiitas

\begin{tabular}{ccccc}
\hline & N & Indikator & Koefisien Korelasi & Ket. \\
\hline Character (X1) & 32 & X1.1 & 0,593 & Valid \\
& 32 & X1.2 & 0,741 & Valid \\
Collateral (X2) & 32 & X1.3 & 0,659 & Valid \\
& 32 & X2.1 & 0,371 & Valid \\
& 32 & X2.2 & 0,386 & Valid \\
& 32 & X2.3 & 0,697 & Valid \\
Condition of Economy (X3) & 32 & X2.4 & 0,553 & Valid \\
& 32 & X2.5 & 0,674 & Valid \\
& 32 & X3.1 & 0,651 & Valid \\
& 32 & X3.3 & 0,665 & Valid \\
Collateral (X4) & 32 & X3.4 & 0,567 & Valid \\
& 32 & X3.5 & 0,623 & Valid \\
& 32 & X3.6 & 0,485 & Valid \\
& 32 & X4.1 & 0,572 & Valid \\
& 32 & X4.2 & 0,529 & Valid \\
& 32 & X4.3 & 0,769 & Valid \\
& 32 & X4.4 & 0,435 & Valid \\
& 32 & X4.5 & 0,659 & Valid \\
& 32 & X4.6 & 0,521 & Valid \\
& 32 & X4.7 & 0,549 & Valid \\
& 32 & Y1 & 0,829 & Valid \\
& 32 & Y2 & 0,930 & Valid \\
& 32 & Y3 & 0,867 & Valid \\
& Y4 & Y5 & 0,883 & Valid \\
& 32 & 0,879 & Valid \\
& 32 & 0,807 & Valid \\
& 32 & & Valid \\
\hline \multirow{3}{*}{ Macet (Y) } & 32 & &
\end{tabular}

Sumber: Data SPSS yang diolah (2017)

Berdasarkan tabel diatas dapat diketahui bahwa indikator-indikator variabel yang terdiri dari character, capacity, condition of economy, collateral dan Kredit Macet telah memenuhi kriteria pengujian 
dengan nilai $\mathrm{r}>0,2869$ dan nilai signifikasi $\mathrm{r}$ korelasi $<$ dari $95 \%$ atau $\alpha=0,05$ yang dapat dikatakan bahwa instrumen penelitian adalah valid.

\section{Uji Reliabilitas Data}

Pengujian reliabilitas dalam penelitian ini, menggunakan Rumus Alpha dimana rangkaian kuesioner dinyatakan reliabilitas jika mempunyai Alpha diatas 0,60 atau dapat dikatakan semua indikator masing-masing variabel dari kuesioner adalah reliabel. Sehingga selanjutnya item-item pada masingmasing variabel tersebut layak untuk diukur.

Tabel 4.7. Uji Reliabilitas

\begin{tabular}{ccc}
\hline Variabel & Cronbach Alpha & Keterangan \\
\hline Character $(\mathrm{X} 1)$ & 0,749 & Reliabel \\
Capacity $(\mathrm{X} 2)$ & 0,697 & Reliabel \\
Condition of economy $(\mathrm{X} 3)$ & 0,731 & Reliabel \\
Collateral $(\mathrm{X} 4)$ & 0,723 & Reliabel \\
Kredit Macet $(\mathrm{Y})$ & 0,800 & Reliabel \\
\hline
\end{tabular}

Sumber: Data SPSS yang diolah (2017)

Berdasarkan pada tabel di atas dapat diketahui bahwa nilai koefisien reliabilitas seluruh instrumen penelitian adalah di atas 0,60, maka dapat disimpulkan bahwa instrumen penelitian ini adalah reliabel.

\section{Uji Regresi Linear}

Analisis regresi linear berganda digunakan dalam penelitian ini dengan tujuan agar mengetahui ada tidaknya pengaruh variabel independen terhadap variabel dependen. Hasil pengolahan data pada penelitian ini, adalah sebagai berikut:

Tabel 8. Hasil Analisis Regresi Coefficients $^{\mathrm{a}}$

\begin{tabular}{|c|c|c|c|c|c|c|c|c|}
\hline \multirow{2}{*}{\multicolumn{2}{|c|}{ Model }} & \multicolumn{2}{|c|}{$\begin{array}{l}\text { Unstandardized } \\
\text { Coefficients }\end{array}$} & \multirow{2}{*}{$\begin{array}{c}\begin{array}{c}\text { Standardized } \\
\text { Coefficients }\end{array} \\
\text { Beta }\end{array}$} & \multirow[t]{2}{*}{$\mathrm{t}$} & \multirow[t]{2}{*}{ Sig. } & \multicolumn{2}{|c|}{$\begin{array}{c}\text { Collinearity } \\
\text { Statistics }\end{array}$} \\
\hline & & B & Std. Error & & & & Tolerance & VIF \\
\hline \multirow{5}{*}{1} & (Constant) & 37,878 & 9,947 & & 3,808 & ,001 & & \\
\hline & X1_Character &,- 838 & ,406 &,- 282 & $-2,064$ & ,049 & ,972 & 1,028 \\
\hline & X2_Capacity &,- 271 & ,279 &,- 138 &,- 970 & ,340 & ,896 & 1,116 \\
\hline & $\begin{array}{l}\text { X3_ConditionOfEcono } \\
\text { my }\end{array}$ &,- 361 & 228 &,- 241 & $-1,580$ & , 126 & ,780 & 1,282 \\
\hline & X4_Collateral &,- 255 & ,073 &,- 529 & $-3,502$ & ,002 & ,795 & 1,258 \\
\hline
\end{tabular}

a. Dependent Variable: Y_KreditMacet

Sumber: Data SPSS yang diolah (2017)

Berdasarkan tabel diatas dapat diperoleh persamaan regresi linier berganda sebagai berikut:

$Y=37,878-0,838 X_{1}-0,271 X_{2}-0,361 X_{3}-0,255 x_{4}+e$

Hasil persamaan regresi linier dapat dinyatakan sebagai berikut: 
1. Konstanta sebesar 37,878 menunjukkan besarnya variabel kredit macet pada saat variabel character, capacity, condition of economy dan collateral tidak mempengaruhi adanya resiko kredit macet, dalam hal ini kredit macet tetap terjadi yang disebabkan oleh faktor lain. Dengan artian, apabila secara keseluruhan kondisi keempat variabel membaik maka justru akan mengurangi kredit macet.

2. $\mathrm{b} 1=-0,838$, merupakan koefisien regresi dari variabel character. Artinya apabila character (kepribadian) debitur semakin baik dalam artian kesadaran untuk patuh membayar angsuran, maka resiko kredit macet yang terjadi akan berkurang, begitu juga sebaliknya, apabila character (kepribadian) debitur kurang baik maka resiko kredit macet yang terjadi akan bertambah, dengan asumsi variabel yang lain konstan.

3. $\mathrm{b} 2=-0,271$, merupakan koefisien regresi dari variabel capacity. Artinya apabila capacity (kemampuan) debitur dalam memenuhi kewajibannya berjalan lancar maka akan mengurangi resiko kredit macet yang terjadi, begitu juga sebaliknya, apabila capacity (kemampuan) debitur dalam memenuhi kewajibannya kurang berjalan lancar maka akan menambah resiko kredit macet yang terjadi, dengan asumsi variabel yang lain konstan.

4. $\mathrm{b} 3=-0,361$, merupakan koefisien regresi dari variabel condition of economy. Artinya apabila condition of economy (kondisi keuangan) dari dabitur relatif baik maka akan mengurangi resiko kredit macet, begitu juga sebaliknya, apabila condition of economy / kondisi keuangan nasabah kurang baik maka akan menambah resiko kredit macet, dengan asumsi variabel yang lain konstan.

5. b4 $=-0,255$, merupakan koefisien regresi dari variabel collateral. Artinya apabila dalam pengajuan kredit debitur memberikan collateral (jaminan) dan dapat dicairkan dengan nilai yang wajar (memenuhi kriteria value dari jaminan itu sendiri) maka akan mengurangi resiko kredit macet yang terjadi, begitu juga sebaliknya, apabila dalam pengajuan kredit debitur tidak memberikan collateral (jaminan) maka akan menambah kredit macet yang terjadi, dengan asumsi variabel yang lain konstan. Apabila debitur sudah dalam status "macet" maka barang jaminan akan disita oleh pihak bank.

\section{Uji Hipotesis}

\section{Uji Serempak (Uji F)}

Uji $\mathrm{F}$ bertujuan untuk menguji hubungan signifikan antara variabel bebas dengan variabel terikat secara simultan atau bersama-sama. Hasil perhitungan regresi secara simultan pada tabel di bawah ini:

Tabel 9. Hasil Uji F

ANOVA $^{\mathrm{a}}$

\begin{tabular}{llrrrrr}
\hline Model & & Sum of Squares & Df & Mean Square & F & \multicolumn{1}{c}{ Sig. } \\
\hline \multirow{4}{*}{1} & Regression & 305,219 & 4 & 76,305 & 7,056 &, $001^{\text {b }}$ \\
& Residual & 292,000 & 27 & 10,815 & & \\
& Total & 597,219 & 31 & & & \\
\hline
\end{tabular}

a. Dependent Variable: Y_KreditMacet

b. Predictors: (Constant), X4_Collateral, X1_Character, X2_Capacity,

X3_ConditionOfEconomy

Sumber: Data SPSS yang diolah (2017)

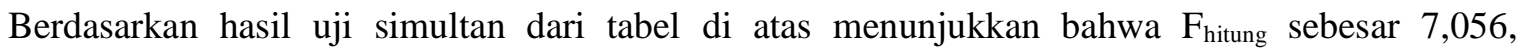
sedangkan hasil $\mathrm{F}_{\text {tabel }}$ pada tabel distribusi dengan tingkat kesalahan 5\%(0,05) adalah sebesar 4,21. Hal ini berarti $F_{\text {hitung }}>F_{\text {tabel }}(7,056>4,21)$. Pada tabel di atas kita juga dapat melihat bahwa nilai signifikansi 0,001 lebih kecil dari 0,05, karena nilai signifikansi lebih kecil dari 0,05 maka model regresi dapat digunakan untuk memprediksi Kredit Macet atau dapat dikatakan bahwa Character, Capacity, Condition of Economy dan Collateral secara bersama-sama (simultan) berpengaruh terhadap Kredit Macet pada PT. Bank Tabungan Negara (BTN) Cabang Bontang. 


\section{Uji Parsial (Uji t)}

Untuk pengujian hipotesis dilakukan dengan cara menggunakan uji t atau uji parsial pada variabel independent terhadap Kredit Macet (Y) dengan menggunakan Level of Significant = 0,05

\section{Tabel 10. Hasil Uji t}

Coefficients $^{\mathrm{a}}$

\begin{tabular}{|c|c|c|c|c|c|c|c|c|}
\hline \multirow[t]{2}{*}{ Model } & & \multicolumn{2}{|c|}{$\begin{array}{l}\text { Unstandardized } \\
\text { Coefficients }\end{array}$} & \multirow{2}{*}{$\begin{array}{c}\begin{array}{l}\text { Standardized } \\
\text { Coefficients }\end{array} \\
\text { Beta } \\
\end{array}$} & \multirow[t]{2}{*}{$\mathrm{T}$} & \multirow[t]{2}{*}{ Sig. } & \multicolumn{2}{|c|}{ Collinearity Statistics } \\
\hline & & $\mathrm{B}$ & Std. Error & & & & Tolerance & VIF \\
\hline \multirow{5}{*}{1} & (Constant) & 37,878 & 9,947 & & 3,808 & ,001 & & \\
\hline & X1_Character &,- 838 & ,406 &,- 282 & $-2,064$ & ,049 & ,972 & 1,028 \\
\hline & X2_Capacity &,- 271 & ,279 &,- 138 &,- 970 & ,340 & ,896 & 1,116 \\
\hline & $\begin{array}{l}\text { X3_ConditionOf } \\
\text { Economy }\end{array}$ &,- 361 & 228 &,- 241 & $-1,580$ &, 126 & ,780 & 1,282 \\
\hline & X4_Collateral &,- 255 & 073 &,- 529 & $-3,502$ &, 002 & ,795 & 1,258 \\
\hline
\end{tabular}

a. Dependent Variable: Y_KreditMacet

Sumber: Data SPSS yang diolah (2017)

Berdasarkan Tabel diatas dapat diketahui besarnya pengaruh masing-masing variabel bebas terhadap variabel terikat sebagai berikut:

a) Pengaruh variabel Character (X1) terhadap Kredit Macet (Y)

b) Tabel di atas menunjukkan bahwa nilai $t_{\text {hitung }}<\mathrm{t}_{0,05}=-2,064<1,703$ dan sig. $<\alpha$ yaitu $0,049<0,05$ secara parsial mempunyai pengaruh signifikan terhadap adanya Kredit Macet (Y) pada BTN Cabang Bontang.Dengan demikian hipotesis $\mathrm{H}_{1}$ dapat diterima.

c) Pengaruh variabel Capacity (X2) terhadap Kredit Macet (Y)

d) Tabel di atas menunjukkan bahwa nilai $t_{\text {hitung }}<\mathrm{t}_{0,05}=-970$ dan sig. $>\alpha$ yaitu 0,340>0,05 secara parsial mempunyai pengaruh tidak signifikan terhadap adanya Kredit Macet (Y) pada BTN Cabang Bontang.Dengan demikian hipotesis $\mathrm{H}_{2}$ ditolak.

e) Pengaruh variabel Condition Of Economy (X3) terhadap Kredit Macet (Y)

f) Tabel di atas menunjukkan bahwa nilai $t_{\text {hitung }}<\mathrm{t}_{0,05}=-1,580$ dan sig. $>\alpha$ yaitu 0,126 $>0,05$ secara parsial mempunyai pengaruh tidak signifikan terhadap adanya Kredit Macet (Y) pada BTN Cabang Bontang.Dengan demikian hipotesis $\mathrm{H}_{3}$ ditolak.

g) Pengaruh variabel Collateral (X4) terhadap Kredit Macet (Y)

h) Tabel di atas menunjukkan bahwa nilai nilai $\mathrm{t}_{\text {hitung }}<\mathrm{t}_{0,05}$ dan sig. $<\alpha$ yaitu $0,002<0,05$ secara parsial mempunyai pengaruh signifikan terhadap adanya Kredit Macet (Y) pada BTN Cabang Bontang.Dengan demikian hipotesis $\mathrm{H}_{4}$ dapat diterima.

\section{SIMPULAN}

Berdasarkan hasil dari analisis dan pembahasan yang telah diuraikan, maka kesimpulan didalam penelitian ini adalah sebagai berikut:

1. Berdasarkan hasil Uji F bahwa Character, Capacity, Condition of Economy dan Collateral secara bersama-sama (simultan) berpengaruh signifikan terhadap Kredit Macet pada PT Bank Tabungan Negara (BTN) Cabang Bontang.

2. Berdasarkan Uji T sacara parsial diketahui bahwa:

a) Character (Karakter) debitur berpengaruh negatif dan signifikan terhadap adanya Kredit Macet. Artinya apabila karakter debitur semakin baik akan mengurangi terjadinya resiko kredit macet, 
begitu juga sebaliknya apabila karakter debitur buruk maka akan meningkatkan resiko kredit macet.

b) Capacity (Kemampuan) berpengaruh negatif dan tidak signifikan terhadap adanya Kredit Macet. Artinya apabila kemampuan debitur dalam memenuhi kewajibannya berjalan lancar maka akan mengurangi resiko kredit macet yang terjadi, begitu juga sebaliknya, apabila capacity (kemampuan) debitur dalam memenuhi kewajibannya kurang berjalan lancar maka akan menambah resiko kredit macet yang terjadi tetapi pengawasan dari pihak harus dengan pengawasan pihak bank itu sendiri karena pejabat analis kreditlah yang bisa mengukur dan mengetahui sejauh mana kemampuan debitur mengembalikan pokok pinjaman serta bunga pinjamannya, sehingga tidak terjadi kredit macet yang merupakan wajah buruk dari cermin kehidupan perbankan.

c) Condition of Economy (Kondisi Keuangan) berpengaruh negatif dan tidak signifikan terhadap Kredit Macet. Semakin baik kondisi keuangan dari debitur maka akan mengurangi resiko kredit macet, begitu juga sebaliknya, apabila kondisi keuangan debitur kurang baik maka akan menambah resiko kredit macet. Sama halnya dengan variabel Capacity, pertimbangan dari pihak banknya sendiri sangat berpengaruh dalam persetujuan pengajuan kredit oleh untuk berjaga-jaga agar hal yang tidak diinginkan tidak terjadi.

d) Collateral (Jaminan) berpengaruh negatif dan signifikan terhadap Kredit Macet. Artinya apabila dalam pengajuan kredit debitur memberikan collateral (jaminan) dan dapat dicairkan dengan nilai yang wajar (memenuhi kriteria value dari jaminan itu sendiri) maka akan mengurangi resiko kredit macet yang terjadi, begitu juga sebaliknya, apabila dalam pengajuan kredit debitur tidak memberikan collateral(jaminan) maka akan menambah kredit macet yang terjadi.

3. Dari keempat faktor dalam penelitian ini, variabel Collateral / Jaminan (X4) merupakan variabel yang memiliki pengaruh paling besar terhadap tingkat kredit macet pada Bank Tabungan Negara Cabang Bontang.

\section{SARAN}

Berdasarkan manfaat penelitian yang telah dikemukakan, dapat memberikan saran sebagai berikut:

1. Bank Tabungan Negara Cabang Bontang dalam menentukan kebijakan-kebijakan yang dilakukan khususnya dalam masalah pemberian kredit kepada nasabah harus benar-benar melakukan pengecekan terhadap calon debitur, seperti menganalisa faktor karakter, kemampuan, kondisi keuangan, dan jaminan debitur, serta faktor internal dari Bank itu sendiri misalnya pengawasan, dari penelitian ini dapat diantisipasi agar tidak menjadi kredit macet yang merupakan wajah buruk dari cermin kehidupan perbankan.

2. Faktor yang paling besar pengaruhnya terhadap kredit macet adalah karakter dan jaminan debitur nasabah, sehingga disarankan kepada pihak bank untuk memberikan perhatian lebih pada faktor ini.

3. Bagi Peneliti dan Akademisi. Bagi penelitian selanjutnya yang berkaitan dengan kredit macet, diharapkan dapat lebih menyempurnakan dan lebih mengkaji lebih lanjut faktor-faktor selain 4 faktor dalam penelitian ini.

4. Bagi Masyarakat. Diharapkan bagi masyarakat dapat menggunakan kredit yang diberikan sesuai dengan keperluan yang telah direncanakan, agar tidak timbul adanya kredit macet. 


\section{DAFTAR PUSTAKA}

Armana, Made Revi. 2015. Analisis Faktor-Faktor Penyebab Terjadinya Kredit Macet pada Lembaga Perkreditan Desa (LPD) di Kabupaten Buleleng. Singaraja: Program S1 Fakultas Ekonomi Universitas Pendidikan Ganesha. (http://ejournal.undiksha.ac.id/index.php/S1ak/article/viewFile/4687/3575, diakeses pada November 2016)

Febrianti, Sitti Rahmah. 2015. Analisis Faktor-Faktor yang Mempengaruhi Kredit Bermasalah di PT. Bank Rakyat Indonesia (Persero) Tbk. Cabang Sengkang. Makassar: Program S1 Fakultas Ekonomi dan Bisnis Universitas Hasanuddin.

Hafiwidjaja, dan Wirasasmita, Rivai. 2007. Analisis Kredit. Bandung: CV. Pionir Jaya Bandung.

Hariyani, Iswi. 2008. Hapus Buku \& Hapus Tagih.Surabaya: PT. Bina Ilmu Offset.

Harmono. 2014. Manajemen Keuangan Berbasis Balanced Scorecard, Edisi Pertama, CetakanKetiga. Bumi Aksara: Jakarta.

Kasmir. 2013. Bank dan Lembaga Keuangan Lainnya. Jakarta: PT. Rajagrafindo Persada.

Mukhsinati, Sari. 2011. Analisis Faktor-Faktor Penyebab Terjadinya Kredit Macet pada Bank " $X$ ” di Kabupaten Jember. Jember: Program S1 Fakultas Ekonomi Universitas Jember. (http://repository.unej.ac.id/bitstream/handle/123456789/5680/Sari\%20Mukhsinati.pdf?sequence=1 diakses pada Agustus 2016)

Mulyawan, Setia. 2015. Manajemen Keuangan, Cetakan Pertama. Pustaka Setia: Bandung.

Priyatno Duwi. 2010. Paham Analisa Statistik Data dengan SPSS. Cetakan Pertama. Yogyakarta: Mediakom.

Siamat, Dahlan. 2001. Manajemen Lembaga Keuangan. Jakarta: Lembaga Penerbit Fakultas Ekonomi Universitas Indonesia.

Sutarno. 2004. Aspek-aspek Hukum Perkreditan pada Bank. Bandung: CV. Alfabeta.

Sutrisno. 2012. Manajemen Keuangan Teori Konsep \& Aplikasi, Cetakan Kedelapan. EKONISIA: Yogyakarta.

Untung, Thamrin. 2005. Kredit Perbankan di Indonesia. Yogyakarta: Penerbit Andi. 